\section{Accessions to the British Museum (Bloomsbury)}

Among recent accessions to the collections of the British Museum (Bloomsbury), reported at the May meeting of the Trustees, is a notable addition to British antiquities. Mr. F. J. Durbin has presented to the Museum the collection of finds made some ten years ago by the late Mr. W. O. Klein when excavating the Romano-British temple at Worth, near Sandwich. It was then found that the Roman temple, built of stone and erected in the second half of the first century A.D., was situated on the site of a prehistoric British shrine of Early Iron Age date, not less than one, and probably four or five centuries earlier. Among the finds were British and Roman brooches, bronze votive offerings in the form of shields, iron and bone implements in large numbers, and a considerable quantity of pottery, ranging from the Iron Age to the Roman occupation. Among antiquities from the East reported at the same time were a fantastic bronze animal figure from Iraq of the older Babylonian period (about 2000 B.c.), and a painted terra-cotta figure of a horseman, which is said to come from Luristan in Persia, and in date is thought to fall between the eighth and fourth centuries B.c. Archæologists who are concerned with western Asia will also be interested in the announcement that a diary kept by Gertrude Lowthian Bell, apparently in Arabia in 1911, has been presented to the Department of Manuscripts by her sister, Lady Richmond. The bequest to the Museum by the late Mr. T. W. Gann of jade objects, pottery and other antiquities from Central America, acquired in the course of his journeys of exploration, has now been received. The jade objects, in accordance with his desire, will be kept together as a unitary collection.

\section{Film Demonstration of Money Movements}

IN view of the recent discussions on "Science and Society" in our columns, many readers will be interested to learn that Prof. M. Polanyi, professor of physical chemistry in the University of Manchester, has produced a short film entitled "An Outline of the Working of Money". The film, which runs for 25 minutes and, except in the opening section, is in diagrammatic form, is divided into five parts. It deals in turn with the circular flow of money, the actions of saving and spending, the functions of the banks, depreciation and the role of the capital goods industries, and finally the interaction of these forces affecting the working of the economic system. In the preparation of the film, simplification of ideas has of course been necessary, but it presents a most interesting venture-so far as we are aware, the first venture-in the application of methods of visual presentation to economic theory. The film was first shown to members of the Manchester Statistical Society in March, and the Society has now published the full script of the film. The film itself, which is at present only available in a silent version, was made by Science Films Limited.

\section{A Psycho-Technical Laboratory}

IN The Engineer of May 13 is an illustrated account of the new Psycho-Technical Laboratory recently erected at Viroflay, near Versailles, for testing candidates for employment on the French State Railways. The laboratory, which is under the direction of Prof. Laugier and his assistant Mlle. Weinberg, is stated to be the most complete of its kind in France. The equipment includes two machines for neuro-muscular tests, an electro-cardiograph, an apparatus for vigilant attention tests, a sound-proof cabin for hearing tests, and an apparatus for testing the candidate's response to visual signals. The room in which the electrocardiograph is installed is completely darkened. The heartbeats of the candidate having been recorded on a moving band of photographic paper, a powerful light is flashed into the eandidate's eyes and a loud and raucous motor-horn sounded, the test being designed to determine the heart's reaction to these sudden stimuli. Tests have been carried out for some years under temporary conditions, but they were not regarded seriously by the railway admin. istration. It being observed that candidates rejected by Prof. Laugier prove less efficient and more prone to accident, has, however, led to the erection of the laboratory.

\section{The Institution of Electrical Engineers}

THE report presented at the annual general meeting on May 12 to the Institution of Electrical Engineers, shows that it is in a very flourishing condition. The membership has increased from 13,561 to 18,252 during the last ten years. The use of the Institution's premises has been granted, without charge, to a number of kindred societies in connexion with their meetings and 188 such meetings have been held during the past year. It has been arranged that as soon as a member of any class has completed fifty years of membership he will automatically cease to be asked any further subscriptions. The Council has decided that facilities to attend Institution meetings and to use the reference library should, as a gesture of good will, be offered to Chinese electrical engineering apprentices and students who, under arrangements made by the Federation of British Industries, have been given opportunities for engineering experience in Great Britain with the object of improving and fostering relations with China. The Council is also giving more active support to the Engineer's 'German Circle'. The lectures given by this Circle are in German and are by eminent German-speaking engineers. On each occasion, they will be followed by a short discussion in German. Those present can thus further their knowledge of technical German.

THE following award of premiums for papers read during the session 1937-38, or accepted for publication have been awarded by the Institution of Electrical Engineers: Institution Premium to A. D. Blumlein, C. O. Browne, N. E. Davis and E. Green ; Ayrton Premium to the late H. W. Clothier and B. H. Leeson and H. Leyburn; Fahie Premium to F. G. Tyack; John Hopkinson Premium to Dr. W. G. Thompson; Paris Exhibition (1881) Premium to J. S. Pickles; Overseas Premiums to Dr. V. K. Zworykin, Dr. G. A. Morton and L. E. Flory ; and 
to Prof. B. L. Goodlet; Extra Premiums to E. T. Norris, D. J. Bolton, A. H. Davis, O. W. Humphreys, C. E. Fairburn, W. Maurice, J. N. Waite; Wireless Section Premiums to T. C. Macnamara and D. C. Birkinshaw ; J. Bell, J. W. Davies and B. S. Gossling ; A. J. Gill and Dr. S. Whitehead; Meter and Instrument Section Premiums to K. J. R. Wilkinson, T. A. Ledward, C. W. Hughes; Transmission Section Premiums to Dr. J. L. Miller and Dr. J. M. Thomson (Sebastian de Ferranti Premium), Dr. S. Whitehead and Mr. E. E. Hutchings.

\section{Centralized Control of Public Lighting}

IN a paper read to the Institution of Electrical Engineers on May 11 by H. Purslove Barker, a full account is given of the new methods of the centralized control of public lighting and off-peak loads, by superimposed ripples. Although clock-switches have to-day reached a high pitch of mechanical perfection, they are only suitable for services where the switching routine is prearranged and invariable. There are very few applications of this kind of switching where the time of the day is the only element which should regulate the operation of a switch. For example, in street lighting the correct time to switch on and off may be determined by the incidence of fog, war or other emergency. By the aid of a central transmitter it is now possible to transmit signals by ripples of current in the distributing and feeding mains, so that one signal acting on a relay turns street lights on, another controls off-peak loads and so on. The system can operate, from a central position, an unlimited number of inexpensive relays. It appears probable that in many areas very restricted lighting will be permitted during war-time, provided that it can be instantaneously extinguished. A centralized ripple control system is now used in Paris for operating warning syrens over a large area. The same ripple that is used to start warning syrens can also be employed to call air-raid wardens in their homes by the aid of a portable relay comprising a bell which can be plugged into any socket in the network. This system of control may prove useful for many purposes in the future.

\section{Recommendations for Seed Potatoes}

Ротато growers when considering the purchase of seed for next year's planting should obtain the leaflet on seed potatoes which the National Institute of Agricultural Botany, Cambridge, issues free of charge. Despite the encouragement given to potato breeding by the Ministry of Agriculture, and Scottish and Irish Departments of Agriculture for many years, more than 90 per cent of the potato acreage in Great Britain is still planted with varieties which have been on the market for more than twenty years. In most cases, newer varieties could be introduced with considerable benefit, and it is suggested that growers who are naturally reluctant to discard varieties with which they are familiar should at least try small quantities of the newer kinds so that they can test for themselves the value of the recommendations made. In the first-early class, Arran Pilot and Doon Early are suggested, while Gladstone,
Redskin and Arran Signet are the recommendations for second-early or main crop potatoes. For late main crop, Dunbar Standard and Arran Cairn both produce white kidney tubers of excellent quality. A number of the older varieties are susceptible to wart disease and possess such faults as poor shape, indifferent cooking quality and proneness to second growth, but these new varieties are immune from wart disease and are only recommended after careful trial. The certificates issued by the Ministry of Agriculture and Scottish and Irish Departments of Agriculture for growing crops of potatoes, are a reliable guide to the standard of health of the purchased seed, and growers should become familiar with the different grades, that they may understand the nature of the guarantee supplied.

\section{Commonwealth Fund Fellowships Awards}

THE Committee of Award of the Commonwealth Fund fellowships has made the following appointments, among others, to fellowships tenable by British graduates in American universities for the two years beginning September 1938. These fellowships are offered by the Commonwealth Fund of New York, of which Mr. Edward S. Harkness is president : Dr. G. H. Benham, University College, London, to the University of Wisconsin, in biochemistry; Dr. Bernard Cannon, University of Liverpool, to Princeton University in mathematics; A. G. Cowan, University of Glasgow, to Brookings Institution, Washington, in economics; M. W. H. Davies, University College of North Wales, Bangor, to the Massachusetts Institute of Technology, in engineering ; K. J. Laidler, Trinity College, Oxford, to Princeton University, in chemistry; E. H. Lee, Gonville and Caius College, Cambridge, to Stanford University, in engineering; M. W. Lister, Oriel College, Oxford, to Harvard University, in chemistry ; J. M. Meek, University of Liverpool, to the University of California, in engineering ; H. B. Parry, Queens' College, Cambridge, University of Edinburgh, and Royal Veterinary College, London, to the University of Wisconsin, in veterinary science; E. R. Roberts, Imperial College of Science and Technology, London, to the University of Minnesota, in agriculture; H. B. Whittington, University of Birmingham, to Yale University, in geology ; P. V. Youle, University of Sheffield, to the University of California, in physical chemistry.

THE following have been appointed to fellowships tenable by candidates from the British Dominions : A. M. Acock, University of Cape Town, and Brasenose College, Oxford, to the University of California, in botany; J. S. de Wet, University of Cape Town, Balliol College, Oxford, and St. John's College, Cambridge, to the Institute for Advanced Study, Princeton, in mathematics. The following have been appointed to fellowships tenable by candidates holding appointments in Government service overseas : J. G. Crawford, University of Sydney, of the Rural Bank of New South Wales, Government of New South Wales, to Brookings Institution and Government agencies, Washington, D.C., in economies ; 